\title{
Characterization of Enzymes Associated with Degradation of Insoluble Fiber of Soybean Curd Residue by Bacillus subtilis
}

\author{
Makoto Shoda and Shinji Mizumoto \\ Chemical Resources Laboratory, Tokyo Institute of Technology, \\ Nagatsuta, Midori-ku, Yokohama, \\ Japan
}

\section{Introduction}

Soybean curd residue is a residue of soy milk processing in which most soluble nutrients of soybean are extracted to liquid phase, and thus major carbon sources of the residue are insoluble fibers (O'tool, 1999) which amount to 40.2- $43.6 \%$ on a dry matter basis (Van der Riet et al.,1989). Approximately 700,000 tons of the soybean curd residue were produced annually as a byproduct of tofu manufacturing in Japan and most of them is incinerated as an industrial waste. We re-utilized the soybean curd residue as a solid substrate of solidstate fermentation (SSF) using Bacillus subtilis (Mizumoto et al., 2006).

The insoluble fibers of soybean consist of cellulose, hemicellulose and lignin. Cellulose is the most abundant biological polymer on earth and is the major constituent of the plant cell wall. This lineal polymer is composed of D-glucose subunits linked by $\beta-1,4$ glycosidic bonds forming cellobiose molecules and the long chains are linked together by hydrogen bonds and van der Waals forces (Perez et al., 2002). Hemicellulose is a complex of polymeric carbohydrates which contains xylan, xyloglucan, (heteropolymer of D-xylose and Dglucose), glucomannan (heteropolymer of D-glucose and D-mannose), galactoglucomannan (heteropolymer of D-galactose, D-glucose and D-mannose) and arabinogalactan (heteropolymer of D-galactose, D-glucose and arabinose). Among them, xylan, a complex polysaccharide comprising a backbone of xylose residues linked by $\beta$-1,4-glycosidic bonds, is the major component. Xylan is the second most abundant polysaccharide in nature, accounting for approximately one-third of all renewable organic carbon on earth (Collins et al., 2005). Lignin is an amorphous non-water soluble and optically inactive heteropolymer. It consists of phenylpropane units joined together by different types of linkages (Perez et al., 2002) Although lignin is the most abundant polymer in wood fiber along with cellulose, its content in non-wood fiber such as straw, grass and seed hull is low (Sun \& Cheng, 2002). The lignin content in the soybean seed coat is reported to be low (Krzyzanowski et al., 2001), and thus it is speculated that the soybean curd residue contains relatively small amount of lignin.

B. subtilis has ability to produce several antibiotics with a variety of structures, especially peptides that are either ribosomally or non-ribosomally synthesized (Leclere et al., 2005; Ongena et al., 2005; Stein, 2005). We previously isolated several strains of B. subtilis and the 
wild strains and their derivatives suppressed 26 types of plant pathogen in vitro (Phae et al., 1990) and a fungal disease in vivo (Asaka \& Shoda, 1996) by producing three lipopeptide antibiotics, iturin A, surfactin and plipastatin (Asaka \& Shoda, 1996; Hiraoka et al., 1992; Tsuge et al., 1996, 1999). The suppressive effect of one of the isolates, B. subtilis RB14, was mainly associated with the cyclolipopeptide antibiotic iturin A, which contains seven $\alpha$ amino acids and one $\beta$-amino acid. B. subtilis RB14-CS, a derivative of the original strain RB14 and a sole producer of iturin A, produced iturin A in SSF using the soybean curd residue 3-fold higher than in submerged fermentation (SmF) (Mizumoto et al., 2006). This suggests that RB14-CS could degrade some kinds of insoluble fibers in soybean curd residue and utilize them as carbon sources during SSF. In this chapter, insoluble fibers in soybean curd residue that RB14-CS could degrade during SSF were clarified and the fiber-degrading enzymes were purified and characterized.

\section{Materials and methods}

\subsection{Strain}

B. subtilis RB14-CS which is a spontaneous mutant derived from RB14-C is a single iturin A producer. B. subtilis RB14-C is a streptomycin-resistant mutant from a parent strain RB14 and is a co-producer of the antibiotics iturin A and surfactin (Asaka \& Shoda, 1996).

\subsection{Solid-state fermentation (SSF)}

The detail of SSF was described in the previous paper (Mizumoto et al., 2006). The L medium used for the growth of the bacterium contained $10 \mathrm{~g}$ of Polypepton (Nippon Pharmaceutical Co., Tokyo, Japan), $5 \mathrm{~g}$ of yeast extract and $5 \mathrm{~g}$ of $\mathrm{NaCl}$ (per liter). One $\mathrm{ml}$ of $\mathrm{L}$ medium culture broth after $24 \mathrm{~h}$ cultivation at $30^{\circ} \mathrm{C}$ was inoculated into $100 \mathrm{ml}$ of number $3 S$ (no. 3S) medium consisting of $30 \mathrm{~g}$ of Polypepton S (Nippon Pharmaceutical Co., Tokyo), $10 \mathrm{~g}$ of glucose, $1 \mathrm{~g}$ of $\mathrm{KH}_{2} \mathrm{PO}_{4}$, and $0.5 \mathrm{~g}$ of $\mathrm{MgSO}_{4} \cdot 7 \mathrm{H}_{2} \mathrm{O}$ (per liter) (pH 6.8), and the culture was incubated at 120 strokes per minute $(\mathrm{spm})$ at $30^{\circ} \mathrm{C}$ for $24 \mathrm{~h}$ in a shaking flask and used as a seed for SSF.

The soybean curd residue was supplied from a tofu company in Tokyo and stored at $-20^{\circ} \mathrm{C}$. Each of fifteen grams of thawed soybean curd residue was placed in a 100-ml conical flask and autoclaved twice at $120^{\circ} \mathrm{C}$ for $20 \mathrm{~min}$ at an interval of 8-12 $\mathrm{h}$ to kill spore-forming microorganisms inhabiting the material. After cooling to room temperature, the following solutions were added as nutrient supplements for every $15 \mathrm{~g}$ of soybean curd residue and moisture content was adjusted to $79 \%: 833 \mu \mathrm{L}$ of $0.45 \mathrm{~g}$ glucose $/ \mathrm{ml}, 75 \mu \mathrm{L}$ of $1 \mathrm{M} \mathrm{KH}_{2} \mathrm{PO}_{4}$, $150 \mu \mathrm{L}$ of $1 \mathrm{M} \mathrm{MgSO}_{4} 7 \mathrm{H}_{2} \mathrm{O}$ and $367 \mu \mathrm{L}$ of deionized distilled water. Then, $3 \mathrm{~mL}$ of an RB14CS culture grown in no. $3 \mathrm{~S}$ medium was added to $15 \mathrm{~g}$ of soybean curd residue and mixed with a stainless steel spatula. All flasks were incubated statically in a water incubator at $25^{\circ} \mathrm{C}$, and at a specified time, one flask was taken and the whole soybean curd residue in a flask was used as a sample for analysis.

\subsection{Preparation of samples for acid and neutral detergent fiber analysis}

After 5 days of SSF by B. subtilis RB14-CS, the whole solid culture was dried by microwave and ground by using a pestle and a mortar. Raw soybean curd residue was used as a control. 


\subsection{Acid and neutral detergent fiber analysis \\ 2.4.1 Acid detergent fiber}

The content of acid detergent fiber, which contains mainly cellulose and lignin, was analyzed in the following manner (Van Soest, 1963). In a $150 \mathrm{~mL}$-flat bottom flask, 0.45 $0.55 \mathrm{~g}$ of ground sample was weighed using micro-balance and $50 \mathrm{~mL}$ of acid detergent solution $(20 \mathrm{~g} / \mathrm{L}$ cetyl trimethylammonium bromide in $0.5 \mathrm{M}$ sulfuric acid) was mixed. The flask was placed in an oil bath under the cold water condenser and boiled within 5-10 min. Sample was refluxed for $60 \mathrm{~min}$ from onset of boil. After approximately $30 \mathrm{~min}$, the inside of flask was washed with minimal amount of acid detergent solution. After refluxed, sample was filtrated under reduced pressure with a tared Gooch crucible. The crucible was washed twice with hot water, then twice with acetone and was dried at $105^{\circ} \mathrm{C}$ overnight. After cooled to room temperature in a desiccator, the weight of the crucible was measured.

\subsubsection{Neutral detergent fiber}

The content of neutral detergent fiber which contained mainly cellulose, lignin, and hemicellulose was analyzed in the following manner (Van Soest, et al., 1991). In a $300 \mathrm{~mL}$ round bottom flask, $0.45-0.55 \mathrm{~g}$ of ground sample, $50 \mathrm{~mL}$ of neutral detergent solution (13.5 $\mathrm{g}$ of sodium dodecyl sulfate, $8.38 \mathrm{~g}$ of EDTA disodium salt, $3.07 \mathrm{~g}$ of $\mathrm{NaB}_{4} \mathrm{O}_{7} \cdot 10 \mathrm{H}_{2} \mathrm{O}, 5.18 \mathrm{~g}$ of $\mathrm{Na}_{2} \mathrm{HPO}_{4} \cdot 12 \mathrm{H}_{2} \mathrm{O}$ and $4.5 \mathrm{~mL}$ of tryethylene glycol per $450 \mathrm{~mL}$ ) and $0.5 \mathrm{~g}$ of sodium sulfite were mixed. The flask was placed in an oil bath under the cold water condenser and boiled for $5 \mathrm{~min}$. After $5 \mathrm{~min}$ of boiling, $2 \mathrm{~mL}$ of a-amylase solution, which consists of heat-stable a-amylase (Kleistase T10S; Daiwa Kasei, Shiga, Japan) and $50 \mathrm{mM}$ sodium phosphate buffer ( $\mathrm{pH}$ 6.0) (1:39 [vol/vol]), were mixed. Then, the sample was refluxed for $60 \mathrm{~min}$. After approximately $30 \mathrm{~min}$, the inside of flask was washed down with minimal amount of neutral detergent solution. After refluxed, the sample was filtrated under reduced pressure with a tared Gooch crucible. The crucible was filled with $2 \mathrm{~mL}$ of a-amylase solution and hot water, and incubated for at least $2 \mathrm{~min}$. Then, the crucible was washed twice with hot water, and then twice with acetone. The crucible was dried at $105^{\circ} \mathrm{C}$ overnight. After cooled to room temperature in a desiccator, the weight of the crucible was measured.

\subsubsection{Calculation of content of insoluble fibers}

As the amount of acid detergent fiber was regarded as total amount of cellulose and lignin, the amount of the neutral detergent fiber minus the amount of acid detergent fiber was regarded as the content of hemicellulose.

\subsection{Iturin A production in liquid culture using insoluble fibers}

In a $200-\mathrm{mL}$ conical flask, $40 \mathrm{~mL}$ of liquid medium consisting of $10 \mathrm{~g}$ of fibrous carbon sources, $10 \mathrm{~g}$ of Polypepton $\mathrm{S}, 1 \mathrm{~g}$ of $\mathrm{KH}_{2} \mathrm{PO}_{4}$ and $0.5 \mathrm{~g}$ of $\mathrm{MgSO}_{4} \cdot 7 \mathrm{H}_{2} \mathrm{O}$ (per liter) (pH 6.8) was prepared. As fibrous carbon sources, xylan (Tokyo Chemical Industry, Tokyo, Japan), avicel, carboxymethyl cellulose, and pectin were used. As a control carbon source, glucose was used. Four hundreds $\mu \mathrm{L}$ of a seeding culture was inoculated into the medium and the flasks were incubated at $30^{\circ} \mathrm{C}$ at $120 \mathrm{spm}$.

For measurement of iturin A concentration, $1 \mathrm{~mL}$ of culture broth was acidified to $\mathrm{pH} 2.0$ with $12 \mathrm{~N} \mathrm{HCl}$. Iturin A was collected by centrifugation at $18,000 \times g$, at $4^{\circ} \mathrm{C}$ for $10 \mathrm{~min}$, and extracted with $1 \mathrm{~mL}$ of methanol. The extract was injected into a high-performance liquid chromatography (HPLC) with a column (Chromolith Performance RP-18eb $4.6 \mathrm{~mm}$ 
diameter $\times 100 \mathrm{~mm}$ height, Merck, Germany) to determine iturin A concentrations. The HPCL system was operated at a flow rate of $2.0 \mathrm{~mL} / \mathrm{min}$ with acetonitrile $-10 \mathrm{mM}$ ammonium acetate $(65: 35$ [vol/vol] $)$ at a column temperature of $40^{\circ} \mathrm{C}$. The elution was monitored at $205 \mathrm{~nm}$ by a UV detector (880-UV, Intelligent UV/VIS Detector, Jasco, Tokyo, Japan).

Although iturin A has 8 homologues with different side-chain structures (Asaka \& Shoda, 1996), the concentration of iturin A was defined as the total amount of five major homologues. The correlation between the peak heights and the concentration of pure iturin A (Sigma-Aldorich, Tokyo, Japan) was used for quantification. Iturin A concentration was expressed as $\mu \mathrm{g} / \mathrm{g}$ initial wet soybean curd residue.

\subsection{Xylanase activity assay}

Dinitrosalicylic acid (DNS) solution was prepared in the following manner. Solution A was prepared by mixing $300 \mathrm{~mL}$ of $4.5 \% \mathrm{NaOH}, 880 \mathrm{~mL}$ of $1 \% 3,5-\mathrm{DNS}$ and $225 \mathrm{~g}$ of potassium sodium (+)-tartrate tetrahydrate. For the preparation of solution $\mathrm{B}, 22 \mathrm{~mL}$ of $10 \% \mathrm{NaOH}$ and $10 \mathrm{~g}$ of phenol was mixed and filled up to $100 \mathrm{~mL}$. To $69 \mathrm{~mL}$ of the mixture, $6.9 \mathrm{~g}$ of $\mathrm{NaHCO}_{3}$ was added. Solutions A and B were mixed thoroughly and placed at room temperature for 2 days. After filtration, the mixture was used as DNS solution.

Xylanase activity was determined by measuring the amount of reducing sugar released from xylan. One hundred $\mu \mathrm{L}$ of enzyme sample was added to $1 \mathrm{~mL}$ of $1 \%$ xylan in $100 \mathrm{mM}$ sodium phosphate buffer $(\mathrm{pH} 6.5)$ in a test tube $(15 \mathrm{~mm} \Phi \times 10.5 \mathrm{~cm})$ and incubated statically at $50^{\circ} \mathrm{C}$ for $5 \mathrm{~min}$. Two $\mathrm{mL}$ of DNS solution was added and cooled immediately in an ice bath. Then the test tubes were boiled for $5 \mathrm{~min}$ and cooled in an ice bath. After centrifugation at $18,000 \times \mathrm{g}$ at $4^{\circ} \mathrm{C}$ for $5 \mathrm{~min}$, absorbance of the supernatant at $540 \mathrm{~nm}$ was measured by spectrophotometer (UV2400; Shimadzu, Kyoto, Japan). Xylose was used as the standard. One unit (U) of xylanase activity was defined as the amount of enzyme that liberates $1 \mu \mathrm{mol}$ of reducing sugars (xylose equivalent) per min.

\subsection{Measurement of xylanase activity during SSF}

SSF was carried out as described in Section 2.2 without addition of glucose. One gram of solid culture sample and $9 \mathrm{ml}$ of sterile distilled water were mixed in a sterile $18-\mathrm{mm}$ diameter test tube, the test tube was vortexed thoroughly and shaken at $150 \mathrm{spm}$ for $5 \mathrm{~min}$ at room temperature. The suspension was centrifuged at $18,000 \times g$ at $4{ }^{\circ} \mathrm{C}$ for $10 \mathrm{~min}$ and the supernatant obtained was used for xylanase assay.

\subsection{Measurement of concentration of protein}

Protein concentrations were determined by the Bradford method (Bradford, 1976) with the Protein Assay Kit II (Bio-Rad, Tokyo, Japan) with bovine serum albumin as the standard protein.

\subsection{Purification of xylanase}

Solid cultures $(90 \mathrm{~g})$ incubated for 5 days in SSF were mixed with $900 \mathrm{~mL}$ of distilled water and stirred for $10 \mathrm{~min}$. The suspension was centrifuged at $6,500 \times \mathrm{g}$ at $4^{\circ} \mathrm{C}$ for $20 \mathrm{~min}$ and the supernatant was frozen at $-20^{\circ} \mathrm{C}$ and then thawed. The sample was centrifuged for removal of polysaccharides under the same condition. Ammonium sulfate was added to the 
supernatant to $30 \%$ saturation, and the precipitate was removed by centrifugation. Then, ammonium sulfate was added to $70 \%$ saturation. The precipitate was recovered by centrifugation, suspended in $50 \mathrm{mM}$ MES buffer ( $\mathrm{pH}$ 6.0) and dialyzed overnight against the same buffer. Then the sample was concentrated by ultrafiltration with YM10 (molecular mass cut-off $10 \mathrm{kDa}$; Advantec, Tokyo, Japan).

The concentrate was applied to a CM-Toyopearl column $(1.3 \mathrm{~cm} \Phi \times 8.3 \mathrm{~cm}$; Tosoh, Tokyo, Japan) pre-equilibrated with buffer A (50 mM MES buffer, $\mathrm{pH} 6.0$ ), and fractions were eluted with a continuous linear gradient of $0-0.5 \mathrm{M} \mathrm{NaCl}$ in buffer A (total volume $120 \mathrm{~mL}$ ). The flow speed and the volume of one fraction were $4 \mathrm{~mL} / \mathrm{min}$ and $8 \mathrm{~mL}$, respectively. In this process, xylanase activity was detected in two fractions, one of which was trapped in the column (Fraction I) and the other was not trapped in the column but passed through (Fraction II). These fractions were subjected to further purification processes.

Fraction I was concentrated using Centriprep YM-10 (molecular mass cut-off $10 \mathrm{kDa}$; Millipore, Tokyo, Japan), diluted with buffer A and applied to a RESOURCES column (0.6 $\mathrm{cm} \Phi \times 3.0 \mathrm{~cm}$; Pharmacia Biotech, Uppsala, Sweden) pre-equilibrated with buffer A. Fractions were eluted with a continuous linear gradient of $0-0.15 \mathrm{M} \mathrm{NaCl}$ in buffer A (total volume $30 \mathrm{~mL}$ ). The flow speed and the volume of one fraction were $1 \mathrm{~mL} / \mathrm{min}$ and $1 \mathrm{~mL}$, respectively. The xylanase active fractions were concentrated with Centriprep YM-10 and applied to a Superdex 75 column $(1.6 \Phi \times 60 \mathrm{~cm}$; Amersham Bioscience, Tokyo, Japan) preequilibrated with buffer A containing $0.2 \mathrm{M} \mathrm{NaCl}$. The elution was carried at a flow rate of 1 $\mathrm{mL} / \mathrm{min}$ and a volume of one fraction was $2 \mathrm{~mL}$.

The $\mathrm{pH}$ of the Fraction II was adjusted to 9.5 by adding $\mathrm{NaOH}$ and applied to a QAEToyopearl $(1.6 \Phi \times 3.7 \mathrm{~cm}$; Tosoh) pre-equilibrated with buffer B $(25 \mathrm{mM}$ piperazine buffer, $\mathrm{pH}$ 9.5), and fractions were eluted with a continuous linear gradient of $0-0.5 \mathrm{M} \mathrm{NaCl}$ in buffer B (total volume $120 \mathrm{~mL}$ ). The flow speed and the volume of one fraction were 4 $\mathrm{mL} / \mathrm{min}$ and $8 \mathrm{~mL}$, respectively. The xylanase active fractions were concentrated with Centriprep YM-10, and fractions were diluted with buffer B and applied to a QAE column. Step elution was performed with $0.07 \mathrm{M} \mathrm{NaCl}$ (total elution volume $96 \mathrm{~mL}$ ). The flow speed and the volume of one fraction were $4 \mathrm{~mL} / \mathrm{min}$ and $8 \mathrm{~mL}$, respectively.

The xylanase active fractions were supplied to the subsequent Butyl-Toyopearl chromatography. A column of Butyl-Toyopearl $(1.6 \Phi \times 4.5 \mathrm{~cm}$; Tosoh) pre-equilibrated with $25 \mathrm{mM}$ piperazine buffer containing $1 \mathrm{M}$ ammonium sulfate was used. Ammonium sulfate was added to the active fractions and its concentration was adjusted to $1 \mathrm{M}$. This solution was then applied to the column and the elution was carried out with a linear gradient of 1-0 $\mathrm{M}$ ammonium sulfate in $25 \mathrm{mM}$ Piperazine buffer (total volume $180 \mathrm{~mL}$ ). The flow speed and the volume of one fraction were $4.5 \mathrm{~mL} / \mathrm{min}$ and $9 \mathrm{~mL}$, respectively.

\subsection{Molecular mass determination}

Sodium dodecyl sulfate-polyacrylamide gel electrophoresis (SDS-PAGE) was performed with a $12.5 \%$ gel in accordance with the Laemmli method (Laemmli, 1970). M. W. Marker "Daiichi" II (Daiichi Pure Chemicals, Tokyo, Japan) was used as a molecular mass marker. After electrophoresis, the gel was stained with Coomassie brilliant blue R-250 (CBB).

\subsection{N-terminal sequence analysis}

SDS-PAGE of xylanases was performed according to the above-described method and then the xylanases on the gel were electroblotted to a commercial membrane (Immobilon-P; 
Millipore, Tokyo, Japan) with a horizontal blotting apparatus (ATTO, Tokyo, Japan). For the blotting of pure enzyme of Fraction II, $0.01 \%$ of SDS was added to transfer buffer to improve protein transfer efficacy. Parts of the membrane blotted with xylanases were cut out and then amino acid sequencing analysis was performed with an amino acid sequencing apparatus (PPSQ-21; Shimadzu, Kyoto, Japan) according to the standard method (Edman, 1949).

Searches for homologous amino acid sequences were performed by a B. subtilis database BSORF (http:/ / bacillus.genome.jp/) and the nonredundant database at The National Center for Biotechnology Information (http://www.ncbi.nlm.nih.gov/) with the BLASTP.

\section{$2.12 \mathrm{pH}$ and temperature profiles and thermostability of xylanases}

Xylanase activity was examined in $\mathrm{pH}$ range of 3.0 to 11.0 . For $\mathrm{pH}$ from 3.0 to $4.0,100 \mathrm{mM}$ sodium citrate buffer was used. For $\mathrm{pH}$ from 4.0 to $6.0,100 \mathrm{mM}$ sodium acetate buffer was used. For $\mathrm{pH}$ from 6.0 to $8.0,100 \mathrm{mM}$ sodium phosphate buffer was used. For $\mathrm{pH}$ from 8.0 to 9.0, $100 \mathrm{mM}$ Tris- $\mathrm{HCl}$ buffer was used. For $\mathrm{pH}$ from 9.0 to 11.0, $100 \mathrm{mM}$ glycine-NaOH buffer was used. To investigate the effect of temperature, the xylanase activity was measured at $20-70^{\circ} \mathrm{C}$ at $\mathrm{pH} 6.5$. Xylanase thermostability was measured at 50,55 and $60^{\circ} \mathrm{C}$.

\subsection{Thin layer chromatography (TLC) analysis of the digestion products}

The digestion products of xylan and xylooligosaccharides (Wako Pure Chemical Industries, Osaka, Japan) by xylanase were analyzed by thin layer chromatography (TLC) according to the method previously reported (Kiyohara et al., 2005) with some modifications.

As a substrate solution, $0.5 \%$ xylan or $0.5 \%$ xylooligosaccharides in $100 \mathrm{mM}$ sodium phosphate buffer $(\mathrm{pH} 6.5)$ was used. In a test tube $(15 \mathrm{~mm} \Phi \times 10.5 \mathrm{~cm}), 0.5 \mathrm{~mL}$ of substrate solution and $0.5 \mathrm{~mL}$ of enzyme solution containing $0.5 \mathrm{U}$ of xylanase in $100 \mathrm{mM}$ sodium phosphate buffer ( $\mathrm{pH}$ 6.5) were mixed and the reaction mixture was incubated at $120 \mathrm{spm}$ at $37^{\circ} \mathrm{C}$. After 1,3 , and $16 \mathrm{~h}$ of incubation, $100 \mu \mathrm{L}$ of reaction mixture was sampled to microtube, and mixed with $200 \mu \mathrm{L}$ of ethanol. Then, the mixture was centrifuged at $18,000 \times g$ for $10 \mathrm{~min}$ and the supernatant obtained was evaporated with a centrifugal concentrator (VC-36N; Taitec, Saitama, Japan). The dried material was dissolved in distilled water and spotted on a Silica Gel 60 TLC plate (Merck, Tokyo, Japan), which was then developed with $n$-butanol/acetic acid/ water (10:5:1, by vol.). After development, the TLC plate was sprayed with aniline hydrogen phthalate reagent. The reagent consisted of $0.93 \mathrm{~g}$ of aniline, $1.48 \mathrm{~g}$ of phthalic anhydride, $84.5 \mathrm{~mL}$ of $n$-butanol and $15.5 \mathrm{~mL}$ of distilled water (Partridge, 1949 ), and heated at $100^{\circ} \mathrm{C}$ to visualize the digestion products.

\section{Results}

\subsection{Degradation of insoluble fibers in soybean curd residue by $B$. subtilis RB14-CS in SSF}

To evaluate the ability of B. subtilis RB14-CS to degrade insoluble fibers in soybean curd residue, residual fibers after SSF were analyzed by acid and neutral detergent fiber methods. The same analyses were repeated three times. The average values of three samples are shown in Figure 1. After SSF of RB14-CS, no change in content of cellulose and lignin was observed. On the other hand, the content of hemicellulose decreased to $15 \%$ of initial one, indicating that RB14-CS degraded hemicellulose in soybean curd residue. 


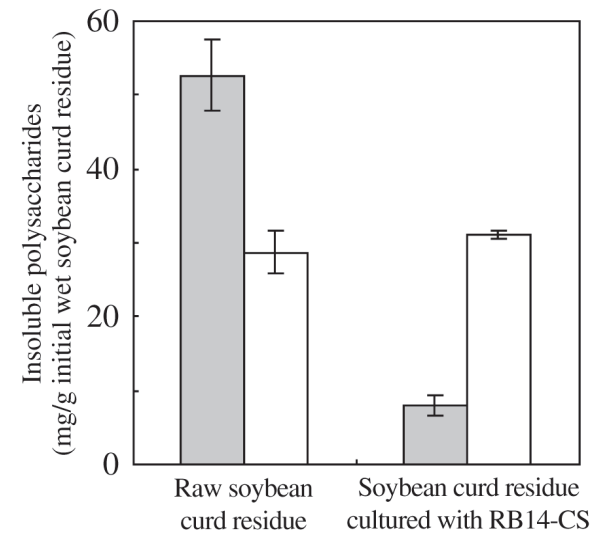

Fig. 1. Analysis of insoluble fiber contents in raw soybean curd residue and soybean curd residue cultured with B. subtilis RB14-CS (N=3). Gray bars, hemicellulose; Open bars, cellulose and lignin.

\subsection{Iturin A production by B. subtilis RB14-CS using insoluble fibers in submerged fermentation}

To investigate the effect of insoluble fibers on iturin A production of RB14-CS, each of insoluble fibers was added to a liquid medium as a carbon source and RB14-CS was cultivated in the medium. Results are shown in Figure 2. Xylan exhibited iturin A production at the same level with glucose which has been used as a carbon source for iturin A production in the previous reports (Asaka \& Shoda, 1996; Tsuge et al., 2001). Other insoluble fibers, avicel and carboxymethyl cellulose, showed the similar level of iturin A production with control where no additional carbon was added. Pectin, a hardly-soluble or sometimes insoluble fiber which is contained in soybean curd residue (Kasai et al., 2004) did not enhance the iturin A production.

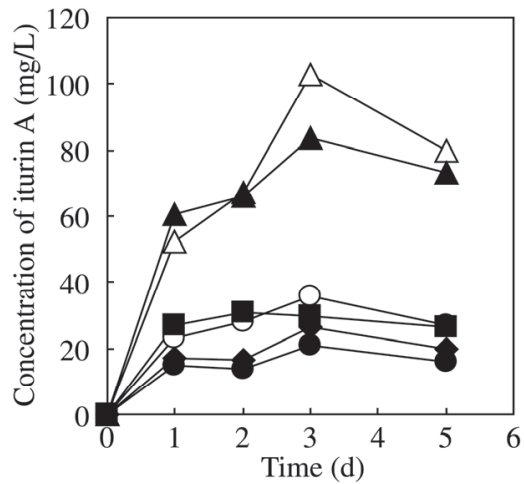

Fig. 2. Iturin A production during submerged fermentation in liquid medium containing fibers $(\mathrm{N}=3)$. Symbols: open circles, no additional carbon sources (control 1); open triangles, glucose (control 2); solid circles, pectin; solid triangles, xylan; solid squares, avicel; solid diamonds, carboxymethyl cellulose. 


\subsection{Xylanase activity of $B$. subtilis RB14-CS during SSF}

As RB14-CS degraded xylan, a major hemicellulose in plant cell wall (Beg et al., 2001), in submerged fermentation, xylanase activity was measured during SSF, in which glucose was not added as medium component. Results are shown in Figure 3. The culture of RB14-CS exhibited xylanase activity in SSF. The activity increased after $12 \mathrm{~h}$ of incubation, reached the maximum value of approximately $50 \mathrm{U} / \mathrm{g}$ wet soybean curd residue at $3 \mathrm{~d}$, and maintained the level during fermentation. When xylanase activity was detected, almost no reducing sugars were detected (data not shown), indicating that RB14-CS immediately utilized the saccharides released from hemicellulose as carbon sources. Changes in cell number and $\mathrm{pH}$ were similar to those in SSF of RB14-CS using soybean curd residue previously reported (Mizumoto et al., 2006).

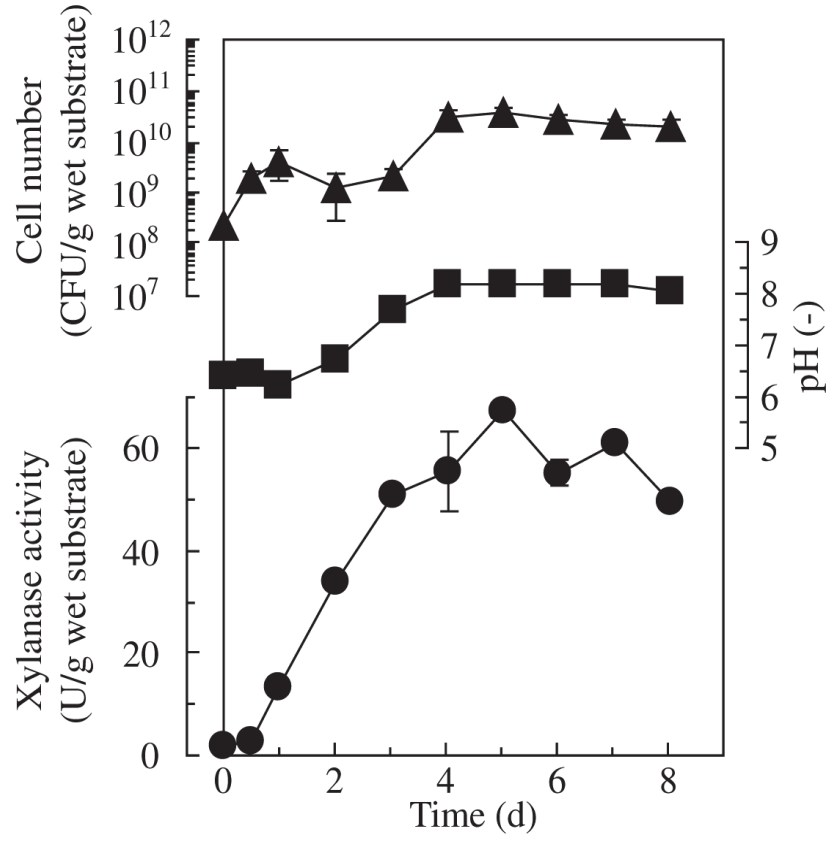

Fig. 3. Xylanase activity of B. subtilis RB14-CS during SSF.

Symbols: circles, xylanase activity; squares, $\mathrm{pH}$; triangles, viable cell number.

\subsection{Purification of xylanases produced by B. subtilis RB14-CS in SSF}

Xylanases were purified as described in materials and methods. When the crude enzyme solution was applied to a cation exchange CM-Toyopearl column, xylanase activity was found in both the trapped fraction (Fraction I) and non-trapped fraction (Fraction II). From these fractions, two enzymes were purified and the two enzymes are homogeneous and have different sizes because each single protein band on SDS-PAGE was observed (Figure 4). This indicates that RB14-CS produces two different xylanases. Purified enzymes of Fraction I and II were designated as Xyl-I and Xyl-II, respectively. The molecular masses of the Xyl-I and Xyl-II estimated from SDS-PAGE were 24 and $58 \mathrm{kDa}$, respectively. 


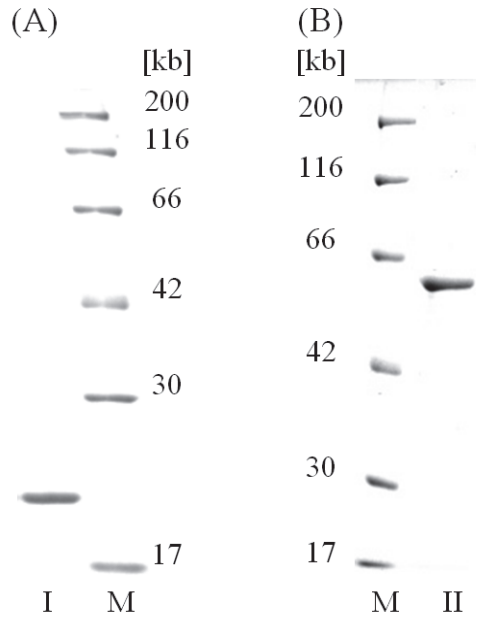

Fig. 4. SDS-PAGE of purified xylanases.(A) Xyl-I, (B) Xyl-II

Lanes: M, molecular mass standards; I, Xyl-I; II, Xyl-II.

\subsection{Physicochemical properties of xylanases}

Effects of temperature and $\mathrm{pH}$ on xylanase activity and thermal stability of the two enzymes are shown in Figure 5. The optimal temperature and optimal $\mathrm{pH}$ of Xyl-I were $50-60^{\circ} \mathrm{C}$ and 6-7, respectively. At $50^{\circ} \mathrm{C}$, approximately $30 \%$ of the initial activity of Xyl-I remained after 3 h. At 55 and $60^{\circ} \mathrm{C}$, Xyl-I was completely inactivated within 2 and $3 \mathrm{~h}$ and the half lives were approximately 18 and $8 \mathrm{~min}$, respectively. The optimal temperature of Xyl-II was $70^{\circ} \mathrm{C}$ or higher and the optimum $\mathrm{pH}$ was $5.5-6$. At $50^{\circ} \mathrm{C}$, approximately $80 \%$ of the initial activity of Xyl-II remained after $3 \mathrm{~h}$. At $60^{\circ} \mathrm{C}$, Xyl-II was inactivated within $3 \mathrm{~h}$ and the half life was approximately $40 \mathrm{~min}$.

\subsection{Analysis of hydrolytic products}

The hydrolysis products released from xylan or xylooligosaccharides by Xyl-I and Xyl-II were analyzed by TLC. From hydrolysis of xylan by both Xyl-I and Xyl-II xylotriose was liberated, but neither xylose nor xylobiose was released. This indicats that these xylanases were not $\beta$-D-xylosidase.

\subsection{Identification of xylanases by $\mathrm{N}$-terminal sequencing and database matching}

The N-terminal sequences of Xyl-I and Xyl-II were determined by automated Edman degradation and compared with databases. Results are summarized in Table 1. Xyl-I displayed $90 \%$ amino acid identity with endo-1,4- $\beta$-xylanase (XynA) of B. subtilis 168, a standard strain whose complete genome has been sequenced (Kunst et al., 1997). The molecular mass estimated by SDS-PAGE was similar to the database value. Moreover, pI value (9.64) of database was identical to that of purified Xyl-I.

Xyl-II has exactly the same $\mathrm{N}$-terminal sequence as a-amylase (AmyE) secreted by $B$. subtilis X-23 (Ohdan et al., 1999). Actually, Xyl-II exhibited a-amylase activity because reducing sugar was increased when soluble starch was treated with Xyl-II (data not shown). It is 

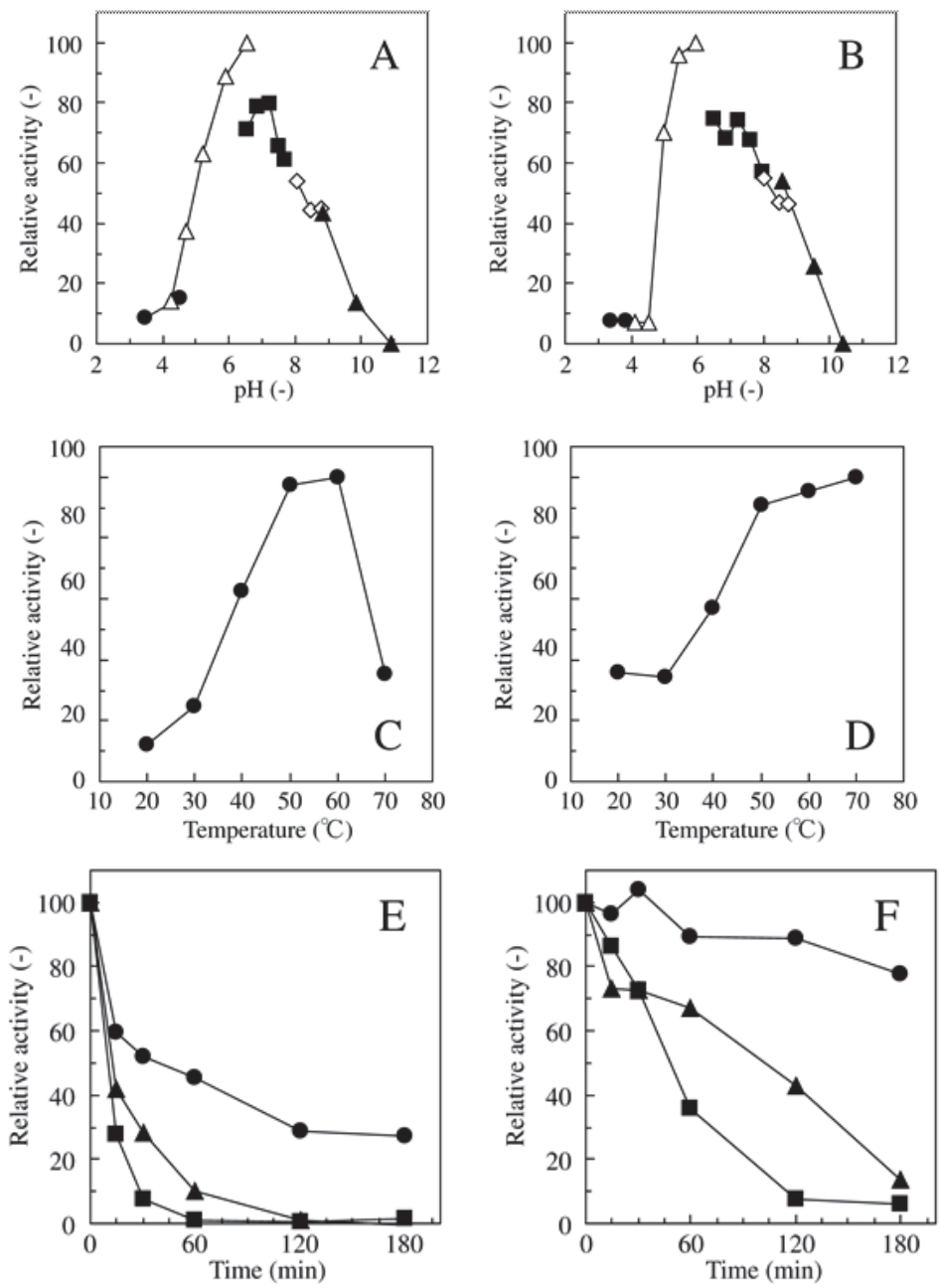

Fig. 5. Effects of $\mathrm{pH}$ and temperature on xylanase activities of Xyl-I and Xyl-II. Effects of $\mathrm{pH}$ on Xyl-I (A) and -II (B), respectively; Effects of temperature on Xyl-I (C) and -II (D), respectively; Thermal stability of Xyl-I (E) and -II (F), respectively. Symbols in (E) and (F): circles, $50^{\circ} \mathrm{C}$; triangles, $55^{\circ} \mathrm{C}$; squares, $60^{\circ} \mathrm{C}$.

assumed that 45 amino acid residues prior to these sequenced residues deduced from the nucleotide sequence of the $B$. subtilis $\mathrm{X}-23$ are the signal peptide that is removed during the secretion process. Xyl-II also displayed $80 \%$ amino acid identity with a-amylase of $B$. subtilis 168 (Kunst et al., 1997). Although the molecular mass of Xyl-II estimated from SDS-PAGE was different from those in the previous reports, the C-terminal structures of a-amylase of $B$. subtilis were reported to be variable (Ohdan, et al., 1999). The $\mathrm{pI}$ value of a-amylase of $B$. subtilis 168 (5.85) was identical with the value of purified Xyl-II. This also reflected in that Xyl-II was trapped in anion exchange chromatography when piperazine buffer of $\mathrm{pH} 9.5$ was used for elution. 


\begin{tabular}{|c|c|c|c|c|c|c|c|c|}
\hline \multicolumn{3}{|c|}{ This work } & \multicolumn{6}{|l|}{ Database } \\
\hline & Sequence & $\begin{array}{l}\text { Size } \\
(\mathrm{kDa})\end{array}$ & Sequence & Gene & $\begin{array}{l}\text { Protein } \\
\text { identity }\end{array}$ & $\begin{array}{l}\text { Size } \\
(\mathrm{kDa})\end{array}$ & $\mathrm{pI}$ & References \\
\hline Xyl-I & AGTDYWQNW & $\Gamma 24$ & ASTDYWQNW & $\Gamma x y n A$ & $\begin{array}{l}\text { endo-1,4- } \\
\beta \text {-xylanase }\end{array}$ & 23 & 9.64 & Kunst et al. \\
\hline Xyl-II & SVKNGTILHA & 58 & SVKNGTILHA & amyE & $\alpha$-amylase & 47,67 & - & $\begin{array}{l}\text { Ohdan et } \\
\text { al. }\end{array}$ \\
\hline & & & SIKSGTILHA & amyE & $\alpha$-amylase & 73 & 5.85 & Kunst et al. \\
\hline
\end{tabular}

Table 1. N-terminal amino acid sequences of purified xylanases.

\section{Discussion}

B. subtilis RB14-CS degraded xylan in soybean curd residue and utilized it as a carbon source during SSF by producing xylanases. Xylanases are produced from xylan by fungi, yeast and bacteria, including Bacillus sp. (Beg et al., 2001; Blanco et al.,1995; Gallardo et al., 2004;Heck et al., 2005; Sa-Pereira et al., 2003) and physicochemical properties, structures and specific activities of these xylanases were diverse.

In this study, two xylanase-active enzymes were isolated. One of them (Xyl-I)was endo-1,4$\beta$-xylanase (XynA), which has been found in many strains of Bacillus sp.( Blanco et al., 1995; Gallardo et al., 2004; Nishomoto et al., 2002). Characteristics of the Xyl-I obtained in this work are similar to those previously reported in that there is $\beta$-D-glucosidase activity and the values of optimum $\mathrm{pH}$ and temperature of Xyl-I are similar to those in other xylanases (Table 2). Another xylanase-active enzyme obtained (Xyl-II) was identified as a-amylase. As shown in Table 2, physicochemical properties of Xyl-II except for molecular mass were similar to those reported previously. Distribution of a-amylase is wide from common mesophilic bacteria to hyperthermophilic archaeon Pyrococcus furiosus (Jorgensen et al., 1997). Alpha-amylase of $B$. subtilis is used commercially in various categories such as starch hydrolysis in starch liquefaction process and additives to detergents for both washing machines and automated dish-washers because of its high thermo-stable activity (Nielsen \& Borchert, 2000). As a-amylase, which catalyzes the hydrolysis and transglycosylation at a1,4- and a-1,6-glycosidic linkages, it doesn't seem to be responsible for degradation of xylan. However, it has been shown that, due to the heterogeneity and structural complexity of xylan, the complete hydrolysis of xylan requires a large variety of cooperatively acting enzymes; such as endo-1,4- $\beta$-D-xylanases, $\beta$-D-xylosidase, $a$-L-arabinofuranosidases, $\alpha-D-$ glucuronidases, acetylxylan esterases, ferulic acid esterases and $p$-coumaric acid esterases (Collins et al., 2005). Thus, a-amylase of RB14-CS which hydrolyzed a-1,4- or 1,6-glucoside linkage in the reagent grade xylan used in this study may act as the cooperatively acting enzymes to release reducing sugars from xylan.

Two enzymes isolated in this work liberated xylooligosaccharides but not xylose from xylan. However, almost no reducing sugars were detected when xylanase activity was detected in SSF. This indicates that RB14-CS degraded xylooligosaccharides into xylose and utilized it as a carbon source. RB14-CS may produce other enzymes such as $\beta$-D-xylosidase for this reaction.

In recent years, biomass containing hemicellulose, such as agricultural and forestry residues, waste paper, and industrial wastes, has been recognized as inexpensive and abundantly available sources of sugar (Katahira et al., 2004). Since the production of iturin A by RB14- 
CS in soybean curd residue was almost equivalent to that when glucose was used as carbon source, the utilization of soybean curd residue will be one possible nutrient in peptide production.

\begin{tabular}{llll}
\hline & This work & References & \\
\cline { 3 - 4 } & & Gallardo et al. & Blanco et al. \\
\hline Molecular mass & $24 \mathrm{kDa}$ & $24 \mathrm{kDa}$ & $32 \mathrm{kDa}$ \\
Optimum pH & $6-7$ & 6 & 5.5 \\
Optimum temperature & $50-60^{\circ} \mathrm{C}$ & $60^{\circ} \mathrm{C}$ & $50^{\circ} \mathrm{C}$ \\
& Decreased to $30 \%$ & Remained stable at $50^{\circ} \mathrm{C}$ & \\
Thermal stability & at $50^{\circ} \mathrm{C}$ after $3 \mathrm{~h}$. & for at least $3 \mathrm{~h}$. & - \\
& Deactivated within & Deactivated within & \\
& $1 \mathrm{~h}$ at $60^{\circ} \mathrm{C}$. & $1 \mathrm{~h}$ at $60^{\circ} \mathrm{C}$. & \\
\hline
\end{tabular}

(A) Xyl-I

\begin{tabular}{llll}
\hline & This work & Reference & (Ohdan et al.) \\
\cline { 3 - 4 } & & Ba-S & Ba-L \\
\hline Molecular mass & $58 \mathrm{kDa}$ & $47 \mathrm{kDa}$ & $67 \mathrm{kDa}$ \\
Optimum pH & $5.5-6.0$ & 5.5 & 5.5 \\
Optimum temperature & $70^{\circ} \mathrm{C}$ & $65^{\circ} \mathrm{C}$ & $65^{\circ} \mathrm{C}$ \\
& $80 \%$ was retained & & \\
Thermal stability & $\begin{array}{l}\text { after } 3 \mathrm{~h} \text { at } 50^{\circ} \mathrm{C} . \\
\text { Deactivated within }\end{array}$ & $60 \%$ was retained & $30 \%$ was retained \\
& $2 \mathrm{~h}$ at $60^{\circ} \mathrm{C}$. & & \\
\hline
\end{tabular}

(B) Xyl-II

Table 2. Comparison of characteristics of purified xylanases with previous reports.

\section{Conclusion}

Soybean curd residue which is the residue of Tofu production was used for nutrients for production of a lipopeptide antibiotic, iturin A in solid state fermentation(SSF) using Bacillus subtilis. As the main carbon sources of soybean curd residue were insoluble fiber, we expected that $B$. subtilis produced the soybean curd residue-degrading enzymes. Among insoluble fibers in soybean curd residue, hemicellulose was mainly degraded by B. subtilis during SSF. Xylan, a major hemicellulose in plant cell wall was degraded by B. subtilis, and two enzymes which showed xylanase activity were purified and identified as endo-1,4- $\beta$ xylanase and a-amylase. As productivity of iturin A in soybean curd residue was almost equivalent to that in glucose medium, this study gave a possible way to use soybean curd residue in higher and economical production of lipopeptides.

\section{References}

Asaka, O. \& Shoda, M. (1996). Biocontrol of Rhizoctonia solani damping-off of tomato with Bacillus subtilis RB14. Applied and Environmental Microbiology, Vol.62, pp. 4081-4085

Beg, Q. K.; Kapoor, M.; Mahajan, L. \& Hoondal, G. S. (2001). Microbial xylanases and their industrial applications: a review. Applied Microbiology and Biotechnology, Vol.56, pp. 326-338 
Blanco, A.; Vidal, T.; Colom, J. F. \& Pastor, F.J. I. (1995). Purification and properties of xylanase A from alkali-tolerant Bacillus sp. strain BP-23. Applied and Environmental Microbiology, Vol.61, pp.4468-4470

Bradford, M. M. (1976). A rapid and sensitive method for the quantification of microgram quantities of protein utilizing the principle of protein-dye binding. Analytical Biochemistry, Vol.72, pp. 248-254

Collins, T.; Gerday, C. \& Feller, G. (2005). Xylanases, xylanase families and extremophilic xylanases. FEMS Microbiological Review, Vol.29, pp. 3-23

Edman, P. (1949). A method for the determination of the amino acid sequence in peptides. Archives of Biochemistry and Biophysics, Vo.11, pp. 475-476

Gallardo, O.; Diaz, P. \& Javier Pastor, F. I. (2004). Cloning and characterization of xylanase A from the strain Bacillus sp. BP-7: Comparison with alkaline pI-low molecular weight xylanases of family 11. Current Microbiology, Vol.48, pp.276-279

Heck, J. X.; Flores, S. H.; Hertz, P. F. \& Ayub, M. A. Z. (2005). Optimization of cellulase-free xylanase activity produced by Bacillus coagulans BL69 in solid-state cultivation. Process Biochemistry, Vol.40, pp.107-112

Hiraoka, H.; Ano, T. \& Shoda, M.(1992). Characterization of Bacillus subtilis RB14, coproducer of peptide antibiotics iturin A and surfactin. Journal of General and Applied Microbiology, Vol.38, pp.635-640

Jorgensen, S.; Vorgias, C. E. \& Antranikian, G. (1997). Cloning, sequencing, characterization, and expression of an extracellular a-amylase from the hyperthermophilic archaeon Pyrococcus furiosus in Escherichia coli and Bacillus subtilis. Journal of Biological Chemistry, Vol.272, pp.16335-16342

Kasai, N.; Murata, A.; Inui, H.; Sakamoto, T. \& Kahn, R. I. (2004).Enzymatic high digestion of soybean milk residue (Soybean curd residue). Journal of Agricultural and Food Chemistry, Vol.52, pp. 5709-5716

Katahira, S.; Fujita, Y.; Mizuike, A.; Fukuda, H. \& Kondo, A. (2004). Construction of a xylanfermenting yeast strain through codisplay of xylanolytic enzymes on the surface of xylose-utilizing Saccharomyces cerevisiae cells. Applied and Environmental Microbiology, Vol.70, pp.5407-5414

Kiyohara, M.; Sakaguchi, K.; Yamaguchi, K.; Araki, T.; Nakamura, T. \& Ito, M. (2005). Molecular cloning and characterization of a novel $\beta-1,3$-xylanase possessing two putative carbohydrate-binding modules from a marine bacterium Vibrio sp. strain AX-4. Biochemical Journal, Vol.388, pp. 949-957

Krzyzanowski F. C.; Franca-Neto, J. B.; Mandarino, J. M. G. \& Kaster, M. (2001). Comparison between two gravimetric methods to determine the lignin content in soybean seed coat. Seed Science and Technology, Vol.29, pp. 619-624

Kunst, F.; Ogasawara, N. \& 149 other authors (1997). The complete genome sequence of the Gram-positive bacterium Bacillus subtilis. Nature, Vol.390, pp.249-256

Laemmli, U. K. (1970). Cleavage of structural proteins during the assembly of the head bacteriophage T4. Nature, Vol.277, pp. 680-685

Leclere, V.; Bechet, M.; Adam, A.; Guez, J.S.; Wathelet, B.; Ongena, M.; Thonart, P.; Gancel, F.; Chollet-Imbert, M. \& Jacques, P. (2005). Mycosubtilin overproduction by Bacillus subtilis BBG100 enhances the organism's antagonistic and biocontrol activities. Applied and Environmental Microbiology, Vol. 71, pp.4577-4584

Mizumoto, S.; Hirai M. \& Shoda, M. (2006). Production of lipopeptide antibiotic iturin A using soybean curd residue cultivated with Bacillus subtilis in solid-state fermentation, Applied Microbiology and Biotechnology, Vol.72, pp.869-875 
Nielsen, J. E. \& Borchert, T. V. (2000). Protein engineering of bacterial a-amylases. Biochimica et Biophysica Acta, Vol.1543, pp.253-274

Nishimoto, M.; Honda, Y.; Kitaoka, M. \& Hayashi, K. (2002). A kinetic study on pH-activity relation ship of XynA from alkaliphilic Bacillus halodurans C-125. Journal of Bioscience and Bioengineering, Vol.93, pp.428-430

Ohdan, K.; Kuriki, T.; Kaneko, H.; Shimada, J.; Takada, T.; Fujimoto, Z.; Mizuno, H. \& Okada, S. (1999). Characteristics of two forms of a-amylases and structural implication. Applied Environmental Microbiology, Vol.65, pp. 4652-4658

Ongena, M.; Jacques, P.; Toure, Y.; Destain, J.; Jabrane, A. \& Thonart, P. (2005). Involvement of fengycin-type lipopeptides in the multifaceted biocontrol potential of Bacillus subtilis. Applied Microbiology and Biotechnology, Vol.69, pp.29-38

O'tool, D. K. (1999). Characteristics and use of soybean curd residue, the soybean residue from soy milk production - A review. Journal of Agricultural and Food Chemistry, Vol.47, pp.363-371

Partridge, S. M. (1949). Aniline hydrogen phthalate as a spraying reagent for chromatography of sugars. Nature, Vol.164, pp. 443

Perez, J.; Munoz-Durado, J.; de la Rubia, T. \& Martinez, J. (2002). Biodegradation and biological treatments of cellulose, hemicellulose and lignin: an overview. International Microbiology, Vol.5, pp. 53-63

Phae, C. G.; Shoda, M. \& Kubota, H. (1990). Suppressive effect of Bacillus subtilis and its products to phytopathogenic microorganisms. Journal of Fermentation and Bioengineering, Vol. 69, pp.1-7

Sa-Pereira, P.; Paveia, H.; Costa-Ferreira, M. \& Aires-Barros, M. R. (2003). A new look at xylanases: an overview of purification strategies. Molecular Biotechnology, Vol.24, pp.257-281

Stein, T. (2005). Bacillus subtilis antibiotics: structures, syntheses and specific functions. Molecular Microbiology, Vol. 56, pp.845-857

Sun, Y. \& Cheng, J. (2002). Hydrolysis of lignocellulosic materials for ethanol production: a review. Bioresources Technology, Vol.83, pp. 1-11

Tsuge, K.; Ano T. \& Shoda, M. (1996). Isolation of a gene essential for biosynthesis of the lipopeptide antibiotics plipastatin B1 and surfactin in Bacillus subtilis YB8. Archives of Microbiology, Vol. 165, pp. 43-251

Tsuge, K.; Ano, T.; Hirai, M.; Nakamura Y. \& Shoda, M. (1999). The genes, degQ, pps and lpa$8(s f p)$ are responsible for conversion of Bacillus subtilis strain 168 to plipastatin production. Antimicrobial Agents and Chemotherapy, Vol. 43, pp. 2183-2192

Tsuge, K.; Akiyama, T. \& Shoda, M. (2001). Cloning, sequencing, and characterization of the iturin A operon. Journal of Bacteriology, Vol.183, pp. 6265-6273

Van der Riet, W. B.; Wight, A. W.; Cilliers, J. J. L. \& Datel, J. M. (1989). Food chemical investigation of tofu and its byproduct soybean curd residue. Food Chemistry, Vol.34, pp.193-202

Van Soest, P. J. (1963) .Use of detergents in the analysis of fibrous feeds. II. A rapid method for the determination of fiber and lignin. Journal- Association of Official Analytical Chemistry, Vol.46, pp. 825-835

Van Soest, P. J.; Robertson, J. B. \& Lewis, B. A. (1991). Methods for dietary fiber, neutral detergent fiber, and nonstarch polysaccharides in relation to animal nutrition. Journal of Dairy Science, Vol. 74, pp. 3583-3597 


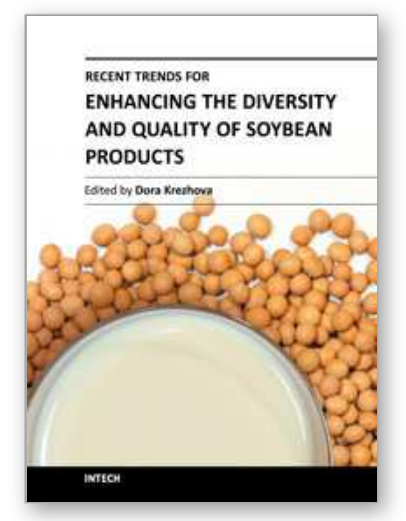

\author{
Recent Trends for Enhancing the Diversity and Quality of Soybean \\ Products \\ Edited by Prof. Dora Krezhova
}

ISBN 978-953-307-533-4

Hard cover, 536 pages

Publisher InTech

Published online 28, October, 2011

Published in print edition October, 2011

This book presents new aspects and technologies for the applicability of soybean and soybean products in industry (human food, livestock feed, oil and biodiesel production, textile, medicine) as well as for future uses of some soybean sub-products. The contributions are organized in two sections considering soybean in aspects of food, nutrition and health and modern processing technologies. Each of the sections covers a wide range of topics. The authors are from many countries all over the world and this clearly shows that the soybean research and applications are of global significance.

\title{
How to reference
}

In order to correctly reference this scholarly work, feel free to copy and paste the following:

Makoto Shoda and Shinji Mizumoto (2011). Characterization of Enzymes Associated with Degradation of Insoluble Fiber of Soybean Curd Residue by Bacillus subtilis, Recent Trends for Enhancing the Diversity and Quality of Soybean Products, Prof. Dora Krezhova (Ed.), ISBN: 978-953-307-533-4, InTech, Available from: http://www.intechopen.com/books/recent-trends-for-enhancing-the-diversity-and-quality-of-soybeanproducts/characterization-of-enzymes-associated-with-degradation-of-insoluble-fiber-of-soybean-curd-residueb

\section{INTECH}

open science | open minds

\section{InTech Europe}

University Campus STeP Ri

Slavka Krautzeka 83/A

51000 Rijeka, Croatia

Phone: +385 (51) 770447

Fax: +385 (51) 686166

www.intechopen.com

\section{InTech China}

Unit 405, Office Block, Hotel Equatorial Shanghai

No.65, Yan An Road (West), Shanghai, 200040, China

中国上海市延安西路65号上海国际贵都大饭店办公楼 405 单元

Phone: +86-21-62489820

Fax: $+86-21-62489821$ 
(C) 2011 The Author(s). Licensee IntechOpen. This is an open access article distributed under the terms of the Creative Commons Attribution 3.0 License, which permits unrestricted use, distribution, and reproduction in any medium, provided the original work is properly cited. 